\title{
Repatriating more than Mapungubwe human remains: Archaeological material culture, a shared future and an artificially divided past.
}

\author{
Maria H. Schoeman, Department of Archaeology, School of Geography, Archaeology \\ and Environmental Studies, University of the Witwatersrand, Braamfontein 2050
}

Innocent Pikirayi, Department of Anthropology and Archaeology, University of Pretoria, Pretoria 0002

\begin{abstract}
Apartheid's lingering ghost ensures that repatriation processes in South Africa are complex. Apartheid ideology not only separated black and white, but also made ethnicity the prime identity for Africans, many of whom internalized it. South Africa's ethicised past ensured that the process of repatriating Mapungubwe human remains was framed in ethnic terms. This resulted in quarrels between claimant communities, who tried to authenticate their claims by proving sole ownership of the human remains. In this potentially volatile context archaeologists were not only negotiating responsible repatriation, but also had to consider their role in a divided present, as squabbles over repatriation could harm both the dead and the living. Fluid group membership involved in the negotiation for the return of human remains from Mapungubwe meant that it would be difficult to exclude any claimants. It was therefore agreed that conflicting oral traditions should be viewed as equal, even when not supported by archaeological data. This acceptance of multivocality resulted in a joint claim by representatives of the Mapungubwe descendants.
\end{abstract}

Keywords: Mapungubwe, repatriation, ethnicity, human remains, archaeology, multivocality

\section{Introduction}

Mapungubwe is situated on the northern border of South Africa, immediately south of the Shashe-Limpoop confluence, where also the borders of South Africa, Botswana and Zimbabwe converge. It is an expanse of 169 hectares of savannah located at the meeting point between the Limpopo and Shashe rivers. In 2003 it was inscribed on UNESCO's World Heritage List, as a site of significance for the interchange of human values, which produced important changes in southern Africa from the ninth to the fourteenth centuries AD. ${ }^{i}$ Mapungubwe was also the site of the earliest kingdom in southern African with extensive regional and continental links involving East Africa, the Arabian Peninsula and the Persian Gulf, India and the Far East. Some seven hundred years later, Mapungubwe centre- stage, as it reassumes importance in the narrative, heritage and politics of the South African nation. This paper considers those contestations and what they might mean for Mapungubwe in particular and cultural heritage in general. Repatriation of human remains and material culture back to descendant communities whom claim them is now a major challenge for archaeologists, museum curators and cultural heritage practitioners in South Africa (Nienaber 2007, Nienaber and Steyn 2002, Nienaber et al 2008a, b). This paper analyses the repatriation of the human remains excavated by archaeologists from the world heritage site of Mapungubwe and other sites nearby in northern South Africa, an area that is now referred to as the Mapungubwe Cultural Landscape (MCL). Mooted repatriation claims of the MCL material culture, and repatriation and reburial of the human remains of 143 individuals have not only been about recognising the claims of local communities, but also about the relevance of the past in the present. At its core, the reburial of the Mapungubwe human remains in 2008 was part of a national ideological process of remaking the voices of black South Africans, who 
were excluded both physically and conceptually from decision making processes about the excavation of human remains. In this remaking, the earliest state in southern Africa, Mapungubwe (AD1220-1290), is invoked as a symbol of pre-colonial African achievement, as well as a key icon of the struggle against racial oppression. This means that on a national ideological level the repatriation of the human remains embodied a broader contest about the character of the pre-colonial African past, varying from a united pan-African past to one characterised by a divisive ethnicity.

In addition to national processes of redress two elements of this past, race and ethnicity have impacted directly on repatriation claims and negotiations about the Mapungubwe human remains and material culture. Undoubtedly, the lingering ghosts of South Africa's colonial and Apartheid past ensures that repatriation processes are complex. A component of this complexity relates to the discipline of archaeology, which was deeply affected by southern Africa's colonial and South Africa's Apartheid past (see e.g. Hall 1984a, Shepherd 2003). The racism entrenched in southern African societies ensured that archaeologists were and remain largely white. ${ }^{\text {ii }}$ In post-colonial Zimbabwe and Botswana the discipline has been transformed and black $^{\text {iii }}$ archaeologists outnumber their white colleagues. Consequently the discipline of archaeology in South Africa is largely perceived as 'untransformed' and government officials and local communities are suspicions of the motives of archaeologists.

Apartheid, however, not only separated black and white South Africans; it also created artificial boundaries between black communities. The state and its allies reified and celebrated pre-colonial identities. The Apartheid state created 'homelands' for these 'nations'. To enforce compliance, urban Africans were dispossessed of their South African citizenship and forced to carry passbooks. In this system access to resources for black South Africans was determined in part by membership to an ethnic group. Thus Apartheid involved the institutionalisation of categories emanating from anthropology. Racial and ethnic segregation emphasised cultural "differences, often translated into stereotypes" (Muthien et al. 2000:154). Volkekunde (Afrikaans version of Cultural Anthropology) (see Sharp 1981, Sharp and Boonzaier 1994) helped to inform the classification of black people into ethnic groups who subsequently were forced into separate homelands. In urban areas fluidity between people from different regions was regarded as problematic and discouraged. Even on the mines, which were one of the largest employers of working class South Africans, workers were classified into ethnic groups and housed in separate areas. Even occupations on the mines, were ethicized (see MacNamara 1978, 1985). Progressive academics (see e.g. Delius 1983, 1989; Dubow 1994) and the southern African liberation movements challenged these ethnic views, but simultaneously South Africans (of all races) internalized this ethicized ideology and ethnic identity often displaced other identities as the prime identity.

Historical sources have helped us understand the creation of ethnicity in the 1900 s, but unfortunately do not provide verifiable insights into pre-colonial identity or ethnicity. Archaeological material culture is one of the few avenues into pre-colonial identity. Archaeologists, however, have been equally culpable in perpetuating the image of feuding, bounded tribes. In spite of the dearth of direct evidence about precolonial identities, images of homogonous ethnic groups permeate South African archaeology irrespective of the archaeological data (Hall 1984a, 1984b; Delius and Schoeman 2010). Much of South African archaeology which examined indigenous African farming communities of the last 1000 years has been framed in culturalhistoric or ethnic terms. Groups are generally viewed as culturally homogenous and 
change is explained as acculturation (for much earlier literature see e.g. Schofield 1937, 1948, for more recent literature, see e.g. 1980, 1989) [for more thorough critiques see e.g. Hall and Maggs (1979), Hall and Mack (1983) and Hall (1984a, 1984b, 1984c)]. In this ethnic or 'tribal' model of southern African archaeology, 'ethnic groups' are identified through the study of ceramic style. Since the 1930s, archaeologists in southern Africa have argued that ceramic style reflects group identity (Hall 1984a, 1984b). Most recently ethnic categories have taken on a new disguise in invocations of indigeneity. These include the Indigenous Knowledge System (IKS) ownership legislation that rests on the assumption that to be indigenous you must belong to a homogenous ethnic group. ${ }^{\text {iv }}$ Most disturbingly, exclusionary claims of belonging have manifested recently in violent xenophobic attacks on people who have fled or migrated to South Africa. During this violence several people were murdered and about 50000 so called 'foreigners' and South Africans who did not fit the profile of 'a local' were displaced.

The tensions associated with racial and ethnic divides also manifested in the repatriation process of the human remains from Mapungubwe, and are visible in mooted claims of the material culture. The continuation of an ethicised past ensured that the repatriation of these remains was framed in ethnic terms, further reinforcing recent historic divisions. Most of the claimant communities are competing in ongoing land claims and many other struggles for resources, which in spite of the legislation are often framed in ethnic terms. These other areas of engagement overshadowed the Mapungubwe repatriation negotiations and contributed to quarrels between the claimant communities, who tried to authenticate their claims by proving sole descent and thus ownership.

\section{Legislative Background}

Framing of the repatriation negotiations were in part due to underdeveloped repatriation legislation. Section 41(1) of the South African National Heritage Resources Act, No. 25 of 1999 ("the NHRA") places an obligation on a publicly funded institution to enter into a process of negotiation with a community or body with a bona fide interest in a movable heritage resource which is part of the national estate, and which is held by such institution regarding the future of such heritage resource where the community or body makes a claim for the restitution of such heritage resource. The legislation has not been enacted in guidelines and there is no specific mention of human remains. This legal lacuna ensures that disputes about the exhumation and academic study of excavated human remains are difficult to resolve. This was clear in the conflict over Prestwich Street human remains excavated by archaeologists, but not studied after objections by some related Cape Town communities (Shepherd 2007).

The Mapungubwe human remains share some similarities as well as fundamental differences with Prestwich Street. They are concerned with memory and identity of previously disadvantaged people in post-colonial or post-Apartheid. The reburial of human remains at both Mapungubwe and Prestwich embody local cultural heritage conservation, Communities feel that the memory and identity of the dead can be restored if burial grounds are preserved (see Shepherd 2007, 12). The Mapungubwe remains, however unlike Prestwich Street, were not an 'accidental' discovery ${ }^{\mathrm{v}}$, but a systematic exhumation and curation from a long, drawn out archaeological programme on Greefswald Farm (Meyer 1998). 


\section{Archaeology and the identity of the Mapungubwe Cultural Landscape}

Throughout the negotiations it was clear the South African government (and at times communities) did not accept archaeological sequencing as more valid than oral traditions. This is in part a response to Apartheid interpretations of history and denial of black voices, but also relates to the manner in which archaeologists have used ceramics as indicators of identity. Racial and cultural identity was the focus of much of southern African archaeology in the twentieth century (Shepherd 2003). The obsession with bounded 'tribes' stands in stark contrast with the flexible and fluid pre-colonial groups and group identities reflected in the historical archive. The MCL is not different. Here, tracing the descendants of the people who lived at Mapungubwe has been the focus of academic research since 1933, when the academic community first encountered Mapungubwe (Fouche 1937, Gardner 1963).

Static identity approaches are clearly materialised in archaeologists' interpretation of the Mapungubwe past. In the first phase of research (1933 to 1941) the research team included historians, archaeologists, anthropologists and linguists. After the first year of excavation - 1934 - researchers concluded that Bantu language speakers had occupied the sites (Fouché 1937; MA D/487). Based on the ceramics found at the sites the archaeologists argued that Mapungubwe and the adjacent Bambandyanalo (K2) hills were occupied by people who spoke a language related to Shona, whereas people of Sotho descent ("Mangwato") occupied K2 (Schofield 1937). They placed the occupation in the 1700's because of the well-preserved San rock art in the area. Arguing that the rock art could not be much older than 300 years, and in classic Apartheid terms that San and black farming communities never lived in the same area at the same time early researchers concluded that Mapungubwe occupation must post date the rock art. Whilst modified, to adjust to a different cultural affiliation and incorporate the thirteenth century radiocarbon dates, this 'tribal' approach to Mapungubwe identity was pervasive for most of the twentieth century. One group replaced another as a series of groups migrated and claimed the area. In this framework group identity is abstracted and communities viewed largely as homogenous, and uniform ceramic traditions are believed to express their identity. Simply put for Mapungubwe archaeologists: pots = bounded groups.

Early skeletal research contradicted the initial archaeological and ethnological findings suggesting the remains were Bush-Boskopoid, thus not black. Partly informed by this racial identification Guy Gardner, who excavated Mapungubwe between 1935 and 1941, argued that the occupants were KhoeKhoe (Gardner 1963). Racial classification (e.g. through craniology) were fundamental to denials of African authorship of Mapungubwe (Galloway 1959), but also in challenging racist denials. More recent physical anthropological research has shown that the Boskopoid identification was incorrect (Rightmire 1970; Steyn 1997). The occupants of Mapungubwe were black Africans. In addition to the black African human remains discussed above, physical anthropologists from the University of Pretoria have also identified San-like features in at least one of the human remains ${ }^{\text {vi }}$.

No DNA research has been conducted yet. DNA analysis of human remains is a destructive process and at this stage in the development of ancient DNA research there is no guarantee that tests will be successful. In addition, contamination is likely as the excavated remains were treated with a range of substances, including gelatine. Hence, archaeologists and physical anthropologists had not conducted DNA tests, rather they have chosen to wait for improvement in methods used to extract ancient DNA, hoping that this will increase the likelihood of success. This position changed in the re-burial process and several requests were made to the committee facilitating 
the repatriation to allow for DNA sampling before reburial. Although some communities requested these tests, they were turned down. But DNA tests would not be able to discriminate between ethnic groupings. In addition to the problem with DNA studies discussed by McEachern (2000), it is unlikely that DNA would be able to untangle this web because Mapungubwe was inhabited before the time that the socio-political groupings, as we know them today, developed and all modern black southern Africans are genetically very similar and therefore it is not possible to distinguish between them using DNA. DNA analysis may only tell us the sex of the individuals, and may also assist in determining if they were of European, African or Khoisan descent. If DNA proves that they were of African descent (as indicated by the skeletal remains), it will inform tell us to which of the three major Haplogroups in Africa they belonged (Soodyall 1993).

Recent research about the formation of the Mapungubwe state reveals complex interactions beyond racial and ethnic homogenous societies. During K2 period (AD 1000 to 1220), a period that preceded Mapungubwe (AD1220 to 1290), at least three groups with different material culture identities were present in the Shashe Limpopo Confluence area. These identities are visible in Leopard's Kopje ceramics, Zhizo-Leokwe ceramics and hunter-gatherer (ancestral San) stone tools. Clearly then the K2-Mapungubwe area was occupied by people with different modes of production as well as ethnic origins. Together these communities shaped the Mapungubwe state, and it is likely that these communities intermarried (Calabrese 2007; Schoeman 2006a, b; van Doornum 2005, 2008). This work resonates with the historical complexity and layered and inter-connected landscape.

\section{The claimants and the claimed}

All known human remains ${ }^{\text {vii }}$ that originated from the Mapungubwe Cultural Landscape were claimed and repatriated (Nienaber et al 2008b). The material culture has not yet been claimed, but communities from the Limpopo Province of South Africa such as the Vhangona, Twamamba and Venda royal representatives have mooted claims. The Vhangona, on numerous occasions, have requested government to assist in the repatriation of the material culture items from Mapungubwe. During the negotiations on the repatriation of human remains - which were facilitated by the University of Pretoria which had most of these remains, but also involved the National Cultural History Museum and the University of the Witwaterand - the Vhangona made a similar request that was however rejected. Venda royals, the Singo, are also rumoured to be making a claim. Most of the mooted claims focus not on the ceramics, faunal or botanical remains, but rather on the trade goods such as glass beads and gold objects.

\section{Negotiating repatriation - contestations, disagreements, and eventual compromise.}

The 1994 elections in South Africa marked the end of the Apartheid state, and the majority of South Africans hoped that they signalled the start of fundamental transformations in South Africa. Believing that the elections also meant changing control over heritage resources, MCL community representatives asked government assistance with repatriation, e.g. the Vhangona sent several requests to the South African provincial and national government that the human remains and all material culture be repatriated. At least one request was sent directly to the University of Pretoria. These claims were either ignored or forwarded to other government agencies. This changed when, Michael Koka, on his deathbed, asked President Thabo 
Mbeki to ensure that the remains of his Mapungubwe Lemba ancestors are taken home. President Mbeki handed the matter to then Deputy Minister of Environmental Affairs and Tourism (DEAT), Rejoice Mabudafasi. DEAT is responsible for South Africa's World Heritage sites and national parks and the Mapungubwe Cultural Landscape is both.

The Deputy-Minister's office launched a repatriation process under the banner of the Mapungubwe human remains Steering Committee. The committee comprised the claimant communities and the University of Pretoria. The University of the Witwatersrand and then Northern Flag Institution (NFI) (now Distong Museums of South Africa) later joined the process later. DEAT was the main facilitator. They worked closely with SANParks and South African Heritage Resources Agency (SAHRA). Also involved was the National Heritage Council and the Freedom Park. Freedom Park representatives played a key reconciliatory role and later led the cleansing ceremonies. The involvement of the national department of Arts and Culture, under which SAHRA resorts, was sporadic.

Deputy Minister Mabudafasi is a member of the Lemba community and it seems that at this stage the South African government assumed the remains were those of Lemba ancestors. In addition Deputy Minister Mabudafasi claimed that DNA tests on the remains indicated that the remains were Lemba. In South Africa the Lemba self-identify as Jews (Buijs 1998, LeRoux 2002, 2003, Thomas et al 2000). Unbeknown to the deputy minister, this claim resonated with earlier (see e.g. Dart 1940, Gardner 1962) and some contemporary claims that Mapungubwe was built by non-Africans, or non-local Africans. Consequently, the implications of the deputyministers claim horrified archaeologists and physical anthropologists familiar with the site and remains. Not only was the claim that the remains are not African false but no DNA studies have been conducted on these human remains (Bonnie-Tamir 2000). Community representatives from other groups who have long argued that they are the descendants of the Mapungubwe people were outraged to the extent that the negotiations almost failed unless the deputy minister recused herself from the process. This was speedily and amicably resolved when such claims were withdrawn and when it was realised that such a claim was at best tenuous and would fail, and other communities were drawn into the process.

The bulk of negotiations involved three communities - the Vhangona, Tshivula and Lemba - and they were the only parties mentioned as 'bona fide descendants' in the original draft claim. After UP questioned the representativity of the process, three additional communities - the San, the Machete and the Leshiba joined the process. The San, the Vhangona and the Twamamba (who comprise the Tshivula, the Machete and the Leshiba) lived in the MCL before the arrival of the Singo royals and their Lemba allies in the seventeenth century, and formation of the Venda state - thus falling in the conceptual 'first people' category. These claimants, however, are not the only communities who have claimed descent from the Mapungubwe people, for example the Tshivase section of the Venda royal family publicly proclaimed descent and the Makhahane section of the Venda royal house instituted a claim on the human remains with the University of Pretoria, which was never formalised. It is not clear why none of the sections of the Venda royal family participated in this claim.

The extent of early consultation is not clear, but soon DEAT chose an inclusive approach "because of the scientific evidence, but also because the department saw the reburial process as a nation building exercise and used this project to help build bridges between communities in the northern Limpopo province, who 
under Apartheid were divided by artificial ethnic boundaries. This approach was aimed at being as inclusive as possible and more important, to meet the requirement set out in the NHRA, embarked on an open process of consultation with all communities who self-identify as the descendants of the people who lived in the Mapungubwe state, or who self-identify as related to the people who lived in the Mapungubwe state. This self-identification was supported by oral traditions supplied to the department by representatives of the communities.

Negotiations took place over a period of two years. The meetings often developed into sites of intense conflict between the various stakeholders. Ultimately, it was Levhuwani Matsila's, the director in the deputy-minister's office, skilful behind-the-scenes leadership and negotiations that ensured trans-ethnic agreement and the final repatriation and reburial of the human remains. Trust between claimants, and between claimants and custodians, was hard won. Trust was built through months of negotiation and collaboration, but even then it was tenuous and context bound. Trust between the claimant community representatives remained flimsy throughout the process. Many are competing in ongoing land claims and many other struggles for resources, which are often framed in ethnic terms. Frequently these other areas of engagement overshadowed the Mapungubwe repatriation negotiations, contributing to quarrels between the claimant communities, who tried to authenticate their claims by proving sole descent and thus ownership. Most meetings and site visits were characterised by insults, verbal attacks and counter-attacks between different claimant community representatives. Throughout the process representatives insisted that their claim was the only valid one and that all other claims were baseless. In attempts to prove that they were the sole descendants, communities presented cultural practices and tradition that would link them to the area, at the request of the Steering Committee. This was an important opportunity for the communities to voice their own histories, and to have government and the academic establishment listen - for once! But it was also the cause of much of the conflict; for communities were essentially forced to 'tell the best story' fearing that if they don't their claim might be dismissed. During the negotiations, community historians re-interpreted settlement sequences in order to explain first people status or belonging to the land. Most of the input from community representatives related to owning and belonging in the area of the MCL. These invoked the old archaeological 'tribal' narrative, over more nuanced recent work, because they could use it to argue for sole ownership over the archaeology

\section{Escaping the ethnic quicksand}

Layered over the complex inter-community wrangles, was a shared belief, expressed by representatives of all the claimants that keeping human remains in museum and university laboratories clashed with African ancestral belief systems around burial and respect for the dead. There was also this realisation that archaeologists need to start listening to the voices of local communities on matters of cultural heritage, specifically the treatment of human remains (Scarre and Scarre 2006). Against this complex background insisting on material proof of cultural affinity - as archaeologists were inclined to do - was impossible and frankly improper. This is was impossible because whilst it is possible that while some material culture can be used to express group identity or ethnicity, there are no communities today making material culture in the Mapungubwe tradition as identified by archaeologists (see Meyer 1998). This was also improper because material culture identities are not eternal and fixed and in this lies the danger of using material culture to track descent from Mapungubwe. Such an approach can easily perpetuate the model that poses 
cultural identity as primary. Thus recourse to archaeological material culture as baseline would re-silence community histories by imposing a new archaeological master narrative. Racial biology or DNA are not alternatives either for they perpetuate South Africa's obsession with racial classification (for a more detailed discussion see Dubow 1990, 1994, 1996). Embedded in Apartheid ethnic classification lies the potential for further conflict amongst the communities of the MCL. In this potentially volatile context (see Lynch 2006 in the case of Kenya) we were not just negotiating responsible repatriation, but archaeologists must also consider their role in a divided present.

The identification of Mapungubwe descendants had to engage with different approaches to descent not purely defined by ethnicity and race, which play such a reductionist and divisive role in current southern African discourse about the precolonial past and descent. If descent can and should not purely be defined by ethnicity and race we had to find another way. The only alternative to a state claim that would silence local voices was the identification of Mapungubwe descendants or relatives using a different approach, not solely 'cultural affiliation' to archaeological material culture (see Ralushai 1977). For archaeologists, this meant trying to ensure acceptance for multivocality amongst competing communities. A multivocal approach was the only way to recognise all the community histories as well as the archaeological one. Everybody eventually accepted this and it was agreed that conflicting oral traditions should be viewed as equal, and archaeological data not privileged. This agreement resulted in acceptance of a joint claim by representatives of the Mapungubwe communities and the UP.

Even on a purely factual level acceptance of a layered and multi-vocal past was the only viable path because of the fluid group membership in the Mapungubwe area. Archaeological research combined with anthropological research suggests that it would be impossible to identify any one community in the area as the only descendants of the people of the Mapungubwe. Simultaneously a critical approach to the data, which recognises fluid group membership, multi-group membership of the K2-Mapungubwe state, in the formation of the Venda kingdom as well as in the historic period provides a model for a way out of an Apartheid inspired ethnic and racial morass.

According to the archaeology after the Mapungubwe state collapsed around $\mathrm{AD}$ 1300, the royals and most of the commoners moved to the north, where they are eventually incorporated into the Great Zimbabwe state (AD 1300 - 1450). Around AD1450 Great Zimbabwe state fragmented into the Mutapa and Khami/Rozvi states. The Singo dynasty, who united the Venda from the 1500s, were Rozvi in origin and thus Venda people formed part of the Mapungubwe-Zimbabwe cultural pattern. Because of this linkage archaeologists have used Venda ethnography to explain Great Zimbabwe and Mapungubwe (see e.g. Huffman 1996, 2005, 2007). Loubser, however, found that 'Venda' consist of an amalgamation of several groups who lived in the area before AD 1650. Interaction between groups shaped a new identity and language. This is supported by the archaeology. Letaba - the ceramic tradition associated with the united Venda kingdom - is derived from Moloko and Khami (with Mapungubwe links) ceramics. Mapungubwe ceramics also continue in the area after the fall of the Mapungubwe capital, until they are eventually replaced by Khami (Loubser 1991). The area united into a kingdom after the arrival of the Singo. Some of the groups in the area today thus have deep roots, but some group-identities were created through more recent interaction (Lestrade 1930, Stayt 1931, Van Warmelo 1935, 1940, 1956). 
In addition to the royal and material cultural affiliations visible in the archaeology, linguistic research has suggested that the Venda language is composed of Shona and Sotho elements as well as an unknown component. The unknown component could be early Karanga - the language spoken at Mapungubwe - and their descendants in this area until the fifteenth century (Beach 1980; Loubser 1991). Mapungubwe people who remained behind when the Mapungubwe state fell around AD 1300 (Loubser 1991), and majority of Mapungubwe people moved north possibly contributed the early Karanga component. These early Karanga / Mapungubwe speakers would have been amongst the 'first people' (e.g. the Ngona and Twamamba) encountered by the Singo, and their Lemba allies, when they settled in the northern Limpopo province (Loubser 1991, 400-421). Archaeologists have been silent about hunter-gatherer history after AD1300, but historical evidence point to a recent San presence in the area (van Doornum 2008).

\section{The new people of Mapungubwe}

After extensive deliberations, UP accepted the joint claim from the communities. This related to internal dynamics and a shift in the balance of power in the university where discussions were characterised by two opposed views which emerged during negotiations - one pro-reburial and the other concerned about compromising the needs of science. The complex processes of building consensus at UP stand in stark contrast with the response from the University of the Witwatersrand when the human remains housed at their medical school were added to the list of claimed human remains. Rather than engage in negotiations the University of the Witwatersrand simply agreed to repatriation and were willing to hand the remains over immediately. The reasons for their willingness to repatriate were never made explicit. NFI's public response was pro-burial, but they did not apply for permission to rebury until the last moment. Public statements by their CEO, Makgolo Makgolo, located repatriation and reburial of human remains in the context of post 1994 process of redress.

The views of all were also taken into account in the reburial. It was agreed to bury in sealed containers in built underground crypts. Any future access would have to be negotiated with all stakeholders. The ceremonies would draw on the practices of all communities. After the reburial processes were completed, and it became clear that no community would benefit financially or gain more prominence than others attitudes towards other communities shifted. People were willing to recognize that their world and histories are not that different from the one recorded in the MCL material culture. Community representatives now started to explicitly acknowledge that they are related. Both on a personal level, e.g. one of the Vhangona representatives had a Lemba mother, and on a historical group scale. These conversations included what they had learnt from the archaeologists about the sequence and material culture. Some of the more exuberant even argued that they should no longer refer to themselves by their old groups names, but all should call themselves the Mapungubwe people. Several people also apologised to the San, and acknowledged that they do belong to the area.

\section{Conclusion}

Enacting multi-vocality was not simple. Truly acknowledging community histories when these embodied ethicised consciousness, created by Apartheid, is a challenge, and at times it would have been easier for archaeologists to silence their voices in favour of the old 'scientific' master narrative. But, to build a post-Apartheid archaeology we need to find ways of listening to community stories and engage rather 
than silencing. One way of doing this is by sharing the past. Archaeology should be shared among archaeologists, between archaeologists and non-archaeologists, and for purposes of enhancing the protection of archaeological heritage. This is an exercise in engaging with issues of the past and the roles the past plays in the present.

Archaeology should no longer be just the science of generating knowledge about the past, but rather how such knowledge is, and should be, communicated to and utilised for the benefit of the public and local communities. Current discussions in archaeologies of engagement are dominated by issues on the role archaeology should play in contemporary society, including matters of social justice, as well as poverty alleviation and economic, social and political empowerment.

A number of issues remain unresolved in the relationship between archaeology and aboriginal communities. Sharing the past means allowing alternative interpretations of the archaeological record (Watkins 2005, 442). Local communities and archaeologists have much to learn from each other, and open communication will help ensure that active learning takes place. Lyn Meskell (2007), in a study of how the past in produced in South Africa, sees the need for:

\footnotetext{
.... a radical revisioning of archaeology and anthropology.... [where $]. .$. archaeology labour $[s]$ in the service of a newly emergent and more equitable nation, to perform a remedial therapeutic service that actively counteracts the centuries of colonial oppression and apartheid erasures that have deeply affected the production of the past and thus future possibilities. Given this particular historical conjecture, archaeology (like all historical disciplines) is being called upon to do double work, a dual project that seeks to address and redress the past and, through the accounts provided, make possible new understandings of identity in present and future social settings. (384) (Emphasis added)
}

Southern Africa's complex pasts can only be successfully disentangled when they are shared appropriately among experts and non-experts.

We should concede that heritage is an interesting and important contemporary phenomenon worthy of investigation. Cultural heritage is really no more than convenient shorthand, with different contexts of use and different phenomena (material, ideational) it comprises in different parts of the world and for different groups of people. Also, because it is a contemporary phenomenon, any attempt to delineate it also has a tendency to alter it as efforts are made to include a particular heritage (national, regional, ethnic, whatever) within the definition. And that will entail a further redefinition, and so on ad infinitum.

\section{Acknowledgements}

This paper was first presented at the $6^{\text {th }}$ World Archaeological Congress held in Dublin, from the $28^{\text {th }}$ of June to the $4^{\text {th }}$ of July 2008 . We would like to thank conference participants for their valuable comments and suggestions. We also acknowledge the views of the claimants of the Mapungubwe human remains, whose energies and perceptions on repatriation were an invaluable source of knowledge which informed this paper. We unreservedly apologise if some of the views given here misrepresent communities and personalities mentioned in this paper. The errors, omissions and interpretations remain our responsibility. 


\section{References}

Beach, D. N. 1980. The Shona and Zimbabwe, 900-1850: an outline of Shona history. Gweru: Mambo Press/London: Heinemann.

Bonne-Tamir, B. 2000. Jewish and Middle Eastern non-Jewish populations share a common pool of Y-chromosaome biallelic haplotypes. PNAS 97 (12): 67696774.

Buijs, G. 1998. Black Jews in the Northern Provice: A study of ethnic identity in South Africa. Ethnic and Racial Studies 21(4): 661-682.

Calabrese, J.A. 2007. The Emergence of Social and Political Complexity in the Shashi-Limpopo Valley of Southern Africa, AD 900 to 1300: Ethnicity, class, and polity (BAR International Series 1617. Cambridge Monographs in African Archaeology 69). Oxford: Archaeopress.

Dart, R.A. 1940. Recent discoveries bearing on human history in Southern Africa. The Journal of the Royal Anthropological Institute of Great Britain and Ireland 70(1): 13-27.

Delius, P. 1983. The Land Belongs to Us: The Pedi polity, the Boers and the British in the nineteenth century Transvaal. Johannesburg: Ravan Press.

Delius, P. 1989. The Ndzundza Ndebele: Indenture and the Making of Ethnic History, 1883-1914. In Bonner, P. (ed) Holding their Ground. Johannesburg: University of the Witwatersrand Press and Ravan Press.

Delius, P. and Schoeman, M. H. 2010. Introduction. African Studies 69 (2): 207-212.

Dubow, S. 1990. Racial Segregation and the Origins of Apartheid. New York: St Martin's.

Dubow, S. 1994. Ethnic Euphemisms and Racial Echoes. Journal of African Studies 20(3): 355-370.

Dubow, S. 1996. Human Origins, Race Typology and the other Raymond Dart. African Studies 55(1): 1-30.

Fouché, L (ed.). 1937. Mapungubwe: An Ancient Bantu civilization on the Limpopo. Cambridge: Cambridge University Press.

Galloway, A. 1959. The skeletal remains of Bambandyanalo. Johannesburg: Wits Press.

Gardner, G.A. 1963. Mapungubwe Volume II. Pretoria: van Schaick.

Hall, M. 1984a. Pots and Politics: Ceramic interpretations in Southern Africa. World Archaeology 15 (3): 262-273.

Hall, M. 1984b. The Burden of Tribalism: The social context of southern African Iron Age Studies. American Antiquity 49(3): 455-467.

Hall, M. 1984c. They Myth of the Zulu Homestead: Archaeology and ethnography. Africa: Journal of the International African Institute 54(1): 65-79.

Hall, M. and Mack, K. 1983. The outline of an eighteenth-century economic system in South-East Africa. The Annals of the South African Museum 91 (2): 163-194.

Hall, M. and Maggs, T. 1979. Nqabeni, A Later Iron Age Site in Zululand. South African Archaeological Bulletin Goodwin Series 3: 159-176.

Hammer, M.F., Redd, A.J., Wood, E.T., Bonner, M.R., Jarjanazi, H., Karafet, T., Santachiara-Benerecetti, S., Oppenheim, A., Jobling, M.A., Jenkins, T., Oster, $\mathrm{H}$.

Hobsbawm, E. 1996. Identity Politics and the Left. New Left Review 217:38-47.

Huffman, T. N. 1980. Ceramics, classification and Iron Age entities. African Studies 29 (2): 123-174.

Huffman, T. N. 1989. Ceramics, settlements and Late Iron Age Migrations. The African Archaeological Review 7: 155-182. 
Huffman, T. N. 1996. Snakes and Crocodiles: Power and symbolism in ancient Zimbabwe. Johannesburg: Witwatersrand University Press.

Huffman, T. N. 2000. Mapungubwe and the origins of the Zimbabwe Culture. In M. Leslie and T. Maggs (eds), Africa Naissance: The Limpopo Valley 1000 years ago. The South African Archaeological Society Goodwin Series 8: 14-29.

Huffman, T. N. 2005. Mapungubwe: Ancient African civilisation on the Limpopo. Johannesburg: Witwatersrand University Press.

Huffman, T. N. 2007. Handbook to the Iron Age: The archaeology of pre-colonial farming societies in southern Africa. Scottsville: University of KwaZulu-Natal Press.

LeRoux, M. 2002. Are the Lemba of South Africa a lost tribe of Israel? BOTSA 11:28.

LeRoux, M. 2003. A lost tribe of Israel in Africa? The case of the Lemba. Pretoria: UNISA Press.

Loubser, J.H.N. 1991. The ethnoarchaeology of the Venda-speakers in South Africa. Navorsing van die Nasionale Museum Bloemfontein 7(8): 1454-464. Bloemfontein: National Museum.

Lynch, G. 2006. Negotiating Ethnicity: Identity Politics in Contemporary Kenya. Review of African Political Economy 107: 49-65.

MacEachern, S. 2000. Genes, Tribes and African History. Current Anthropology 41(3): 357-371.

Mapungubwe Archive - MA D/487: Report on certain ethnological investigations in connection with the archaeological discoveries at Mapungubwe. Unpublished document, University of Pretoria.

McNamara, J.K. 1978. Social life, ethnicity and conflict in a gold mine hostel. MA dissertation, University of the Witwatersrand.

McNamara, J.K. 1985. Black worker conflicts on South African gold mines, 19731982. Johannesburg: University of the Witwatersrand.

Meskell, L. 2007. Falling Walling and Mending Fences: Archaeological ethnography in the Limpopo. Journal of Social Archaeology 33 (2): 383-400.

Meyer, A. 1998. The Archaeological Sites of Greefswald. Pretoria: University of Pretoria Press.

Muthien, Y.G., Khosa, M.M. and Magubane, B.M. 2000. Democracy and Governance Review: Mandela's Legacy, 1994-1999. Pretoria: Human Sciences Research Council.

Nienabar, W. C. 2007. Report on the archaeological investigation of localities indicated as the possible burial place of Chief Fadana and his companions, Robben Island. Archive file at the Dept of Anatomy, University of Pretoria

Nienaber W. C., Steyn, M. and Hutten, L. 2008a. The grave of King Mgolombane Sandile Ngqika: Revisiting the legend. South African Archaeological Bulletin 63 (187): 46-50.

Nienaber, C., Keough, N., Steyn, M. and Meiring, J. H. 2008b. Reburial of the Mapungubwe Human Remains: An overview of the process and procedure. South African Archaeological Bulletin 63 (188): 164-169.

Nienaber, W. C. and Steyn, M. 2002. Archaeology in the Service of the Community: The repatriation of the remains of Nontetha Bungu. South African Archaeological Bulletin 57 (176): 80-84.

Ralushai, V.N.M.N. 1977. Conflicting Accounts of Venda history with particular reference to the role of the Mutupo in the social organisation. Unpublished $\mathrm{PhD}$ thesis, Queens University, Belfast. 
Ranger, T. 1992. The Invention of Tradition in Colonial Africa. In Hobsbawm, E. and Ranger, T. (eds). The Invention of Tradition. Cambridge: Cambridge University Press.

Rightmire, G.P. 1970. 'Iron Age skulls from southern Africa re-assessed by multiple discriminant analysis', African Journal of Physical Anthropology, 33(2): 147168.

Scarre, C. and Scarre, G. (eds.) 2006. The Ethics of Archaeology: Philosophical perspectives on archaeological practice. Cambridge: Cambridge University Press.

Schoeman, M.H. 2006a. Clouding Power? Rain-control, space, landscapes and ideology in Shashe-Limpopo State Formation. PhD thesis, University of the Witwatersrand.

Schoeman, M.H. 2006b. Imagining Rain-Places: Rain-control and changing ritual landscapes in the Shashe-Limpopo Confluence Area, South Africa. South African Archaeological Bulletin 61(184): 152-165.

Schofield, J. F. The pottery of the Mapungubwe district. In Fouché, L. (ed) 1937. Mapungubwe: An Ancient Bantu Civilization on the Limpopo. Cambridge: Cambridge University Press 32-62.

Schofield, J. F. 1948. Primitive pottery: An introduction to South African ceramics, prehistoric and protohistoric. Handbook Series 3. Cape Town: South African Archaeological Society.

Sharp, J.S. 1981. The Roots and Development of Volkekunde in South Africa. Journal of Southern African Studies 8(1): 16-36.

Sharp, J.S. and Boonzaier, E. 1994. Ethnic Identity as Performance: Lessons from Namaqualand. Journal of African Studies 30 (3): 405-415.

Shepard, N. 2003. 'State of the Discipline: Science, culture and identity in South African archaeology, 1870-2003'. Journal of Southern African Studies 29 (4): 823-844.

Shepherd, N. 2007. Archaeology Dreaming: Post-apartheid urban imaginaries and the bones of the Prestwich Street dead. Journal of Social Archaeology 7(3): 3-28.

Soodyall, H. 1993. Mitochondrial DNA polymorphisms in southern African populations. PhD thesis: University of the Witwatersrand.

Stayt, H.A. 1931. The Bavenda. Frank Cass \& Co. Ltd.

Steyn, M. 1997. 'A reassessment of the human skeletons from K2 and Mapungubwe, South Africa. South African Archaeological Bulletin 52:14-20.

Thomas, M.G., Parfitt, T., Weiss, D.A., Skorecki, K., Wilson, J.F., Le Roux, M., Bradman, N. and Goldstein, D.B. 2000. Y Chromosomes Travelling South: The Cohen Haplotype and the Origins of the Lemba - the "Black Jews of Southern Africa". American Journal of Human Genetics 66: 674:686.

Ucko, P. 1987. Academic Freedom and Apartheid: The story of the World Archaeological Congress. London: Duckworth.

Van Doornum, B.L. 2005. Changing Places, Spaces and Identity in the ShasheLimpopo Region of Limpopo Province, South Africa. PhD thesis, University of the Witwatersrand.

Van Doornum, B.L. 2008. Sheltered from change: hunter-gatherer occupation of Balerno Main Shelter, Shashe-Limpopo confluence area, South Africa. Southern African Humanities 20: 249-28484.

Van Warmelo, N.J. 1935. A preliminary survey of the Bantu tribes of South Africa. Pretoria: Government Printer. 
Van Warmelo, N.J. (ed) 1940. The copper miners of Musina and the early history of the Soutpansberg. Ethnological Publications 8. Pretoria: Government Printer.

Van Warmelo, N.J. 1956. Grouping and ethnic history. In Schapera, I. (ed). The Bantu speaking tribes of South Africa, 43-66. Cape Town: Maskew-Miller.

Watkins, J. 2005. Through Wary Eyes: Indigenous perspectives on archaeology. Annual Review of Anthropology 34: 429-49.

\section{Notes on contributors}

Maria H. Schoeman is a lecturer in Archaeology at the University of the Witwatersrand, South Africa. Her research explores African Farming Community archaeology in the Eastern Cape, Limpopo and Mpumalanga Provinces, and combines multiple sources, such as oral histories and archaeological material culture, to build a more subtle and complex understanding of pre-colonial South Africa. She has also been, and continues to be involved in a variety of community based and public heritage initiatives. She can be contacted at alex.schoeman@wits.ac.za

Innocent Pikirayi is Professor in Archaeology at the University of Pretoria. He researches on the southern African later Iron Age, specifically on the archaeology of Mapungubwe, Great Zimbabwe and post Great Zimbabwe periods. His primary interest on cultural heritage focuses on the relationships between archaeology and the public, specifically on the relevance of archaeological practice to descendant communities. His monograph entitled Tradition, Archaeological Heritage and Communities in the Limpopo Province of South Africa is currently going through peer review pending publication by OSSREA. He can be contacted at innocent.pikirayi@up.ac.za

\section{Notes}

\footnotetext{
${ }^{\mathrm{i}}$ http://whc.unesco.org/en/list/1099 (Accessed 10 June 2011)

ii Race does not determine ideological positions and a few southern African archaeologists did challenge these oppressive systems (see e.g. Ucko 1987).

iii The term black was intensively interrogated during the anti-Apartheid struggle and within the Congress movement came to mean people with African, 'Coloured' and Indian ancestors. The use of the term shifted in post-Apartheid South Africa and is now more frequently used to mean people with African Bantu- language speaking ancestors and excludes people with 'Coloured' and Indian ancestors. This contemporary usage of 'black' generally also excludes people who self identifies as KhoeSan. In this paper our use of the term follows that of the Congress movement.

iv Eternal and homogenous ethnic groups were fundamental to Apartheid policy. Historical research has shown that these categories are deeply flawed and that people in pre-colonial southern African, in fact, did not arrange themselves into homogenous ethnic groups. Rather, fluidity and multi-ethnic groups were common.

${ }^{\mathrm{v}}$ We place the world accidental in quotation marks because it speaks of the selective historical amnesia of developers in Cape Town. Burials are all but unexpected in a layered urban landscape.

${ }^{\mathrm{vi}}$ We recognise that racial classification is flawed as amongst other flaws it assumes that groups do not intermingle.

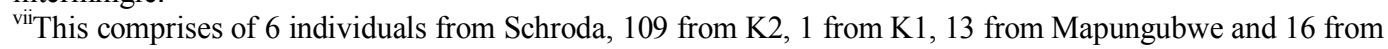
various locations on the park.
} 